Home > Materials Science > Ceramics > Processing and Properties of Advanced Ceramics and Composites Vl: Ceramic Transactions, Volume 249 > Summary

\section{BOOK TOOLS}

(P) Save to My Profile

= Purchase a print copy

$\Rightarrow$ Recommend to Your

Librarian

\section{BOOK MENU}

Book Home

\section{GET ACCESS}

How to Get Online Access

FOR CONTRIBUTORS

For Authors

\section{Fracture Toughness Enhancement of Mullite-Ceramics Reinforced with Metals}

J.P. Singh, Narottam P. Bansal, Amar S. Bhalla, Morsi M. Mahmoud, Navin Jose Manjooran, Gurpreet Singh, Jacques Lamon, Sung R. Choi, Gary Pickrell, Kathy

Lu, Geoff Brennecka andTakashi Goto

Elizabeth Refugio-García', José G. Miranda Hernández ${ }^{2}$, José A. RodríguezGarcia $^{3}$ and Enrique Rocha-Rangel ${ }^{3}$

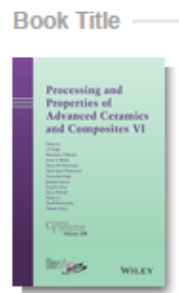

Processing and Properties of Advanced Ceramics and Composites Vl: Ceramic Transactions, Volume 249

Published Online: 3 OCT 2014

DOI: $10.1002 / 9781118995433 . c h 5$

Copyright @ 2014 The American Ceramic Society. All rights reserved.

Additional Information (Hide All)

How to Cite | Author Information | Publication History | ISBN Information:

How to Cite

Refugio-García, E., Hernández, J. G. M.., Rodríguez-García, J. A. and Rocha-Rangel, E. (2014)

Fracture Toughness Enhancement of Mullite-Ceramics Reinforced with Metals, in Processing and Properties of Advanced Ceramics and Composites Vl: Ceramic Transactions, Volume 249 (eds J.P. Singh, N. P. Bansal, A. S. Bhalla, M. M. Mahmoud, N. J. Manjooran, G. Singh, J. Lamon, S. R. Choi, G. Pickrell, K. Lu, G. Brennecka and T. Goto), John Wiley \& Sons, Inc., Hoboken, NJ, USA. doi: $10.1002 / 9781118995433 . c h 5$

Author Information

1 Departamento de Materiales, Universidad Autónoma Metropolitana, Av San Pablo 180 Col., Reynosa-Tamaulipas, México, D. F., 02200

2 Universidad Autónoma del Estado de México (UAEM-Valle de México), IIN, Blvd.,

Universitario $\mathrm{S} / \mathrm{N}$. Predio San Javier, 54500, Atizapán de Zaragoza, Edo. Mex. México.

3 Universidad Politécnica de Victoria, Ave. Nuevas Tecnologías 5902, Parque Científico y, Tecnológico de Tamaulipas, Ciudad Victoria, Tamaulipas, México, 87138

Publication History

Published Online: 3 OCT 2014

Published Print: 5 SEP 2014

\begin{tabular}{l} 
Home \\
Journal Rankings \\
Journal Search \\
Country Rankings \\
Country Search \\
Compare \\
Map Generator \\
Help \\
About Us \\
Show this information in \\
your own website \\
cites doc \\
cites \\
Ceramic Transactions \\
\hline Valua
\end{tabular}

Display journal title

\section{Journal Search}

Search query

\begin{tabular}{|lll}
\hline 10421122 & in Journal ISSN $\mathbf{v}$ Search \\
\hline
\end{tabular}

$\square$ Exact phrase

\section{Ceramic Transactions}

Country: United States

Subject Area: Materials Science

Subject Category:

Category

Quartile (Q1 means highest values and Q4 lowest values)

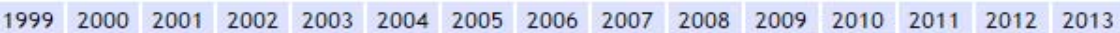

Ceramics and Composites

Materials Chemistry

Publisher: American Ceramic Society. Publication type: Book Series. ISSN: 10421122

Coverage: 2003-2013

H Index: 10

Scope:

Ceramic Transactions (CTs) books contain papers presented at the Annual Meeting of the American Ceramic Society, other regional and division conferences, as well as meetings held by related societies and organizations. (source)

Charts 


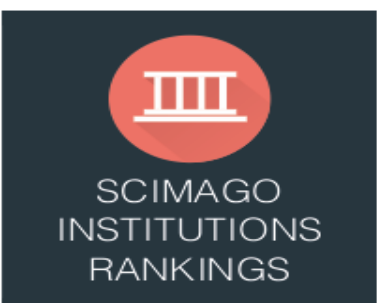

@scimago

SJR is developed by:

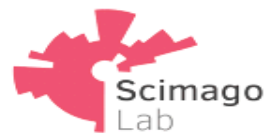

Scopus

How to cite this website?

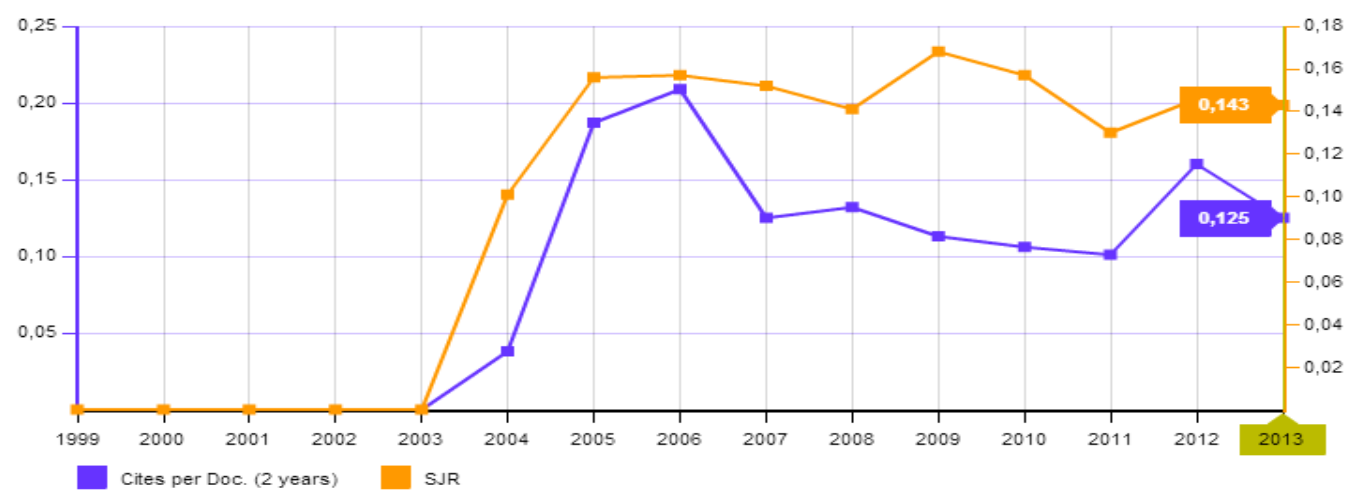

The SJR indicator measures the scientific influence of the average article in a journal, it expresses how central to the global scientific discussion an average article of the journal is. Cites per Doc. (2y) measures the scientific impact of an average article published in the

journal, it is computed using the same formula that journal impact factor ${ }^{\text {nn }}$ (Thomson Reuters).

\section{Citation vs. Self-Citation}

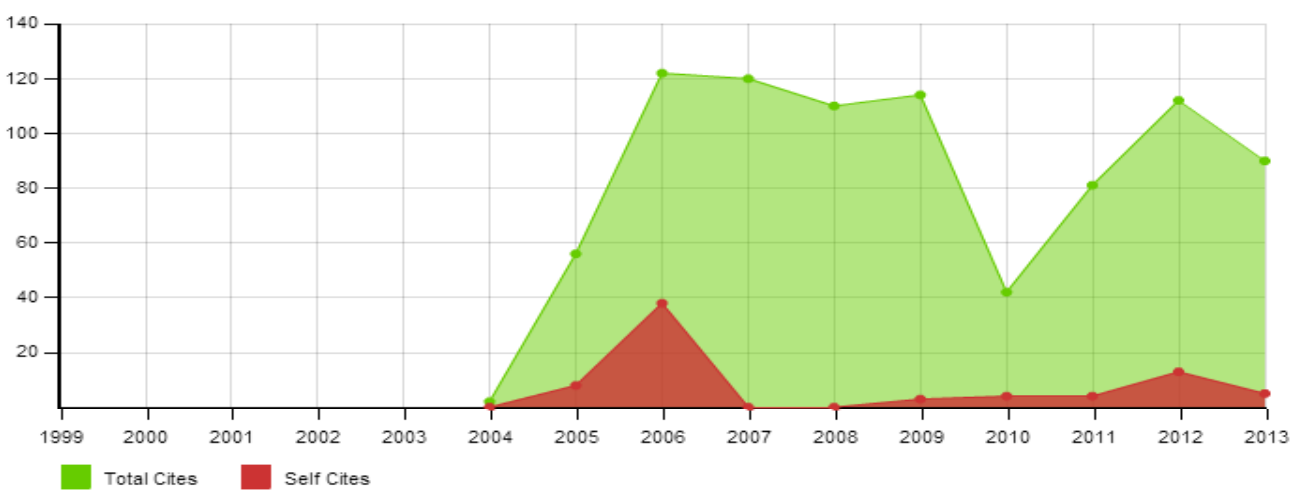

Evolution of the total number of citations and journal's self-citations received by a journal's published documents during the three previous years. 


\section{Processing and Properties of Advanced Ceramics and Composites VI}

Edited by

J. P. Singh

Narottam P. Bansal

Amar S. Bhalla

Morsi M. Mahmoud

Navin Jose Manjooran

Gurpreet Singh

Jacques Lamon

Sung R. Choi

Gary Pickrell

Kathy Lu

Geoff Brennecka

Takashi Goto

\section{Ceramic \\ Crransactions \\ Volume 249}

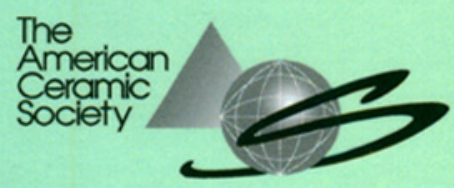




\section{Processing and Properties of Advanced Ceramics and Composites VI}

Ceramic Transactions, Volume 249

Edited by

J.P. Singh

Narottam P. Bansal

Amar S. Bhalla

Morsi M. Mahmoud Navin Jose Manjooran Gurpreet Singh Jacques Lamon Sung R. Choi Gary Pickrell Kathy Lu Geoff Brennecka Takashi Goto

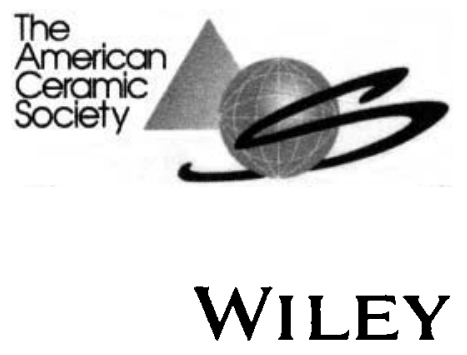


Copyright 2014 by The American Ceramic Society. All rights reserved.

Published by John Wiley \& Sons, Inc., Hoboken, New Jersey.

Published simultaneously in Canada.

No part of this publication may be reproduced, stored in a retrieval system, or transmitted in any form or by any means, electronic, mechanical, photocopying, recording, scanning, or otherwise, except as permitted under Section 107 or 108 of the 1976 United States Copyright Act, without either the prior written permission of the Publisher, or authorization through payment of the appropriate per-copy fee to the Copyright Clearance Center, Inc., 222 Rosewood Drive, Danvers, MA 01923, (978) 750-8400, fax (978) $750-4470$, or on the web at www.copyright.com. Requests to the Publisher for permission should be addressed to the Permissions Department, John Wiley \& Sons, Inc., 111 River Street, Hoboken, N.J 07030, (201) 748-6011, fax (201) 748-6008, or online at http:/www.wiley.com/go/permission.

Limit of Liability/Disclaimer of Warranty: While the publisher and author have used their best efforts in preparing this book, they make no representations or warranties with respect to the accuracy or completeness of the contents of this book and specifically disclaim any implied warranties of merchantability or fitness for a particular purpose. No warranty may be created or extended by sales representatives or written sales materials. The advice and strategies contained herein may not be suitable for your situation. You should consult with a professional where appropriate. Neither the publisher nor author shall be liable for any loss of profit or any other commercial damages, including but not limited to special, incidental, consequential, or other damages.

For general information on our other products and services or for technical support, please contact our Customer Care Department within the United States at (800) 762-2974, outside the United States at (317) $572-3993$ or fax (317) $572-4002$.

Wiley also publishes its books in a variety of electronic formats. Some content that appears in print may not be available in electronic formats. For more information about Wiley products, visit our web site at www.wiley.com.

\section{Library of Congress Cataloging-in-Publication Data is available.}

ISBN: 978-1-1 18-99549-5

ISSN: $1042-1122$

Printed in the United States of America. 


\section{Contents}

Preface

\section{CERAMIC MATRIX COMPOSITES}

Fabrication of Novel $\mathrm{ZrO}_{2}\left(\mathrm{Y}_{2} \mathrm{O}_{3}\right)-\mathrm{Al}_{2} \mathrm{O}_{3}$ Ceramics Having High Strength and Toughness by Pulsed Electric-Current Pressure Sintering (PECPS) of Sol-Gel Derived Solid Solution Powders

Ken Hirota, Kengo Shibaya, Masaki Kato, and Hideki Taguchi

SiC Manufacture via Reactive Infiltration

Mario Caccia and Javier Narciso

Fabrication and Characterization of Conductive Glass Composites with Networks of Silicon Carbide Whiskers

Timothy L. Pruyn and Rosario A. Gerhardt

Alumina-Titanium Composites with Improved Fracture Toughness and Electrical Conductivity

Sergio J. Esparza-Vázquez, Néstor L. Echavarría Méndez, Roxana R. García

García, Ana D. Ramírez-Esparza, Juan López-Hernández, José A.

Rodriguez-García, Enrique Rocha-Rangel, and Elizabeth Refugio-García

Fracture Toughness Enhancement of Mullite-Ceramics Reinforced with Metals

Elizabeth Refugio-Garcia, José G. Miranda Hernández , José A. Rodríguez-García, and Enrique Rocha-Rangel

\section{INNOVATIVE PROCESSING}

Steel-Ceramic Laminates Made by Tape Casting-Processing and Interfaces

Anne Bergner

Comparison of Wax Extraction Methods used in Synthetic Granular Composite Sport Surfaces

John W. Bridge, Robert Fisher, Tina Lai, and Michael Peterson 


\section{FRACTURE TOUGHNESS ENHANCEMENT OF MULLITE-CERAMICS REINFORCED WITH METALS}

\section{Elizabeth Refugio-García}

Departamento de Materiales, Universidad Autónoma Metropolitana, Av. San Pablo 180, Col. Reynosa-Tamaulipas, México, D. F., 02200

José G. Miranda Hernández

Universidad Autónoma del Estado de México (UAEM-Valle de México), IIN, Blvd.

Universitario S/N, Predio San Javier, 54500, Atizapán de Zaragoza, Edo. Mex., México.

José A. Rodríguez-García and Enrique Rocha-Rangel

- Universidad Politécnica de Victoria, Ave. Nuevas Tecnologías 5902, Parque Científico y

Tecnológico de Tamaulipas, Ciudad Victoria, Tamaulipas, México, 87138

\section{ABSTRACT}

With the idea to determine ways of tailoring mullite-ceramics $\left(3 \mathrm{Al}_{2} \mathrm{O}_{3} \cdot 2 \mathrm{SiO}_{2}\right)$ in order that one or more toughening mechanisms are activated in service, investigations about the production of mullite-based composites with different reinforcement metals $(\mathrm{Co}, \mathrm{Ni}, \mathrm{Ti})$ have been carried out. The synthesis of composites materials has been made by means of pressure less sintering of an intensive mechanical mixture of powders. With the use by separate of those metals in the chemical formulations, significant improvements in ceramic toughness have been obtained. From the fracture toughness measurements and microstructural observations, it can be commented that the toughening mechanism in the mullite/metal reinforced composites is due to crack bridging and crack deflection, owed to the presence of ductile particles in the ceramic matrix. On the other hand, the presence of metals in the composites helps densification of mullite.

\section{INTRODUCTION}

In all its applications, ceramic materials are valued for their ability to resist heat and chemical attack, as well as its high hardness. These virtues are due to the strong links that keep the constituent atoms in their positions of balance $e^{1-3}$. The nature of these links also adds a critical drawback which is the fragility, causing that ceramics are particularly sensitive to the presence of minimal imperfections in its microstructure, defects that act as points of cracks initiation ${ }^{2}$. Therefore, many ceramic research efforts have been devoted to develop new processes that minimize these microscopic defects; and it has insisted on the design of new compositions and microstructures that prevent the growth of cracks, where they have result that the combinations between ceramic composites and metals present good mechanical properties ${ }^{4-9}$.

Mullite is a cheap refractory ceramic with a nominal composition of $3 \mathrm{Al}_{2} \mathrm{O}_{3} \cdot 2 \mathrm{SiO}_{2}$. The raw materials for produce mullite are easily obtainable and are reasonably priced. It has excellent high temperature properties with improved thermal shock and thermal stress resistance owing to the low thermal expansion, good strength and interlocking grain structure ${ }^{2}$. Values of the main properties of the mullite are shown in Table 1. 
Fracture Toughness Enhancement of Mullite-Ceramics Reinforced with Metals

Table 1. Main properties of pure mullite at room temperature ${ }^{10}$.

\begin{tabular}{|c|c|}
\hline Property & Value \\
\hline Thermal expansion coefficient & $5 \times 10^{-6} \mathrm{~K}^{-1}$ \\
\hline Flexural resistance & $200 \mathrm{MPa}$ \\
\hline Fracture toughness $\left(\mathrm{K}_{\mathrm{IC}}\right)$ & $2 \mathrm{MPam}-1 / 2$ \\
\hline Young modulus & $231 \mathrm{MPa}^{-1 / 2}$ \\
\hline Density & $3.16 \mathrm{gcm}^{-3}$ \\
\hline
\end{tabular}

As seen in this table, a characteristic in which mullite is deficient is its low fracture toughness $\left(\mathrm{K}_{\mathrm{IC}}\right)$. Furthermore, to obtain dense bodies of mullite, it is required long sintering treatment at temperatures above $1700^{\circ} \mathrm{C}^{10}$, this is due to the high value of the activation energy necessary for ion diffusion occurs through the network of mullite ${ }^{10}$. Therefore, as all ceramics, mullite presents high sensibility to minimal imperfection in its structure, being the main reason for its high fragility. For these reasons, they have been sought alternative methods of production and strengthening of mullite, varying reinforcement materials, the manufacturing process, sintering treatments and even the use of sintering additives that improve the mechanical properties principally fracture toughness ${ }^{11}$. The objective of this work is to manufacture mullitebased composites reinforced with different metals such as: Titanium, nickel and cobalt, in order to enhance their fracture toughness. This through a combination of techniques: mechanical grinding-pressing cold and sintering without pressure.

\section{EXPERIMENTAL}

Raw materials for the production of composites were: Mullite powders $(99.9 \%, 1 \mu \mathrm{m}$, Sigma-Aldrich, USA), titanium, cobalt and nickel powders (99.9 \% purity, 1-2 $\mu \mathrm{m}$, SigmaAldrich, USA). The amount of metallic powders used to obtain the desire composite was that allows at the end of the processing let to obtain a Mullite- $10 \mathrm{vol} . \% \mathrm{Me}$, where Me represents the corresponding metal used as a reinforcement. The powders were milled and dry mixed in a horizontal mill (Cole-Parmer jar mill, $115 \mathrm{VAC} / 60 \mathrm{~Hz}$, USA), using a rotation speed of $300 \mathrm{rpm}$, during 12 hours, with the help of ceramic jars and using YSZ's balls as grinding elements, the ratio; weight of balls/weight of powder was 20:1. Cylindrical samples were fabricated by uniaxial pressing with the milled powders, using 300MPa. Dimension of samples were: $20 \mathrm{~mm}$ diameter and $3 \mathrm{~mm}$ thickness (Montequipo 10,000 Ton. México). Afterwards, samples were pressureless sintered at $1400^{\circ} \mathrm{C}$ during 2 hour in an electrical furnace with argon atmosphere. (Carbolite RHF $16 / 3,1600^{\circ} \mathrm{C}$, UK). The rates of heating and cooling were kept constant and equal to $10^{\circ} \mathrm{Cmin}^{-1}$. The characterization of the synthesized products was as follows: density was evaluated by the Archimedes' principle $\mathrm{e}^{12}$, microhardness measurements were evaluated with the help of a Vickers indenter (Mitutoyo, MVK-H2 H3 HM114, Japan), using a load of 1Kgf with penetrations of $15 \mathrm{~s}$. Fracture toughness measurements were carried out by the fracture indentation method ${ }^{13-15}$. The microstructure of the composites was observed with an optical microscope (Nikon, Eclipse MA 100, Japan). Finally, phases present in the composites materials were determine by X-ray diffraction (Philips, D-5000, Germany). 


\section{RESULTS}

Density

The results of density measurements, evaluated by the Archimedes' principle are shown in Figure 1. In this figure it can see that in all three cases in which the mullite was reinforced with a metal, got a degree of densification superior compared to pure sample. This can be due to the fact that having metal particles homogeneously distributed in the mullite ceramic matrix, the conduction of heat in the samples is best, favoring transport of material during sintering of samples, which is reflected in samples with higher densification. Specimens reinforced with titanium and nickel reached relative densities of $95 \%$ and $94 \%$ respectively, while the sample with cobalt reached $91 \%$ of densification. Furthermore, pure mullite densified slightly less than $86 \%$.

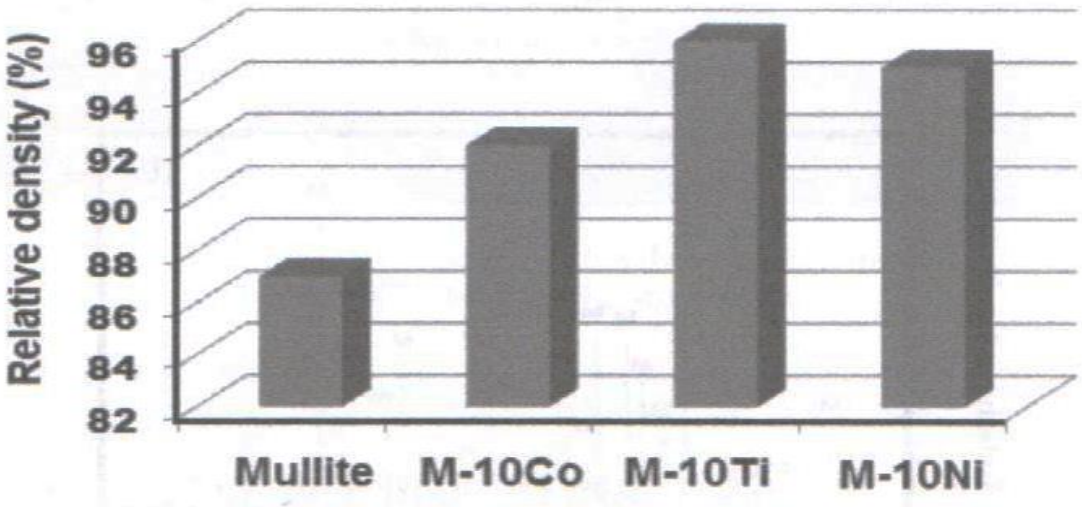

Figure 1. Relative density of the sintered samples at $1400^{\circ} \mathrm{C}$ during 1 hour.

X-ray diffraction

Results of X-rays analysis diffraction of the samples are showed in Figure 2. In these figures for each case clearly shows the presence of intense peaks of mullite. Meanwhile, that also clearly visible in each diffraction pattern the presence of the corresponding reinforcing metal used; as is the case of titanium in Figure 2a, nickel in Figure $2 \mathrm{~b}$ and cobalt in Figure $2 \mathrm{c}$. In these three diffraction patterns it is not observed the presence of any other crystalline component in the samples, as would be any metal oxide used, which may have formed during the sintering, which indicates that the argon atmosphere used for inhibiting the oxidation of metals complied well with its function, of these diffraction patterns is determined that neither one has any contamination in samples, that may come from any of the processing steps, particularly the grinding. 

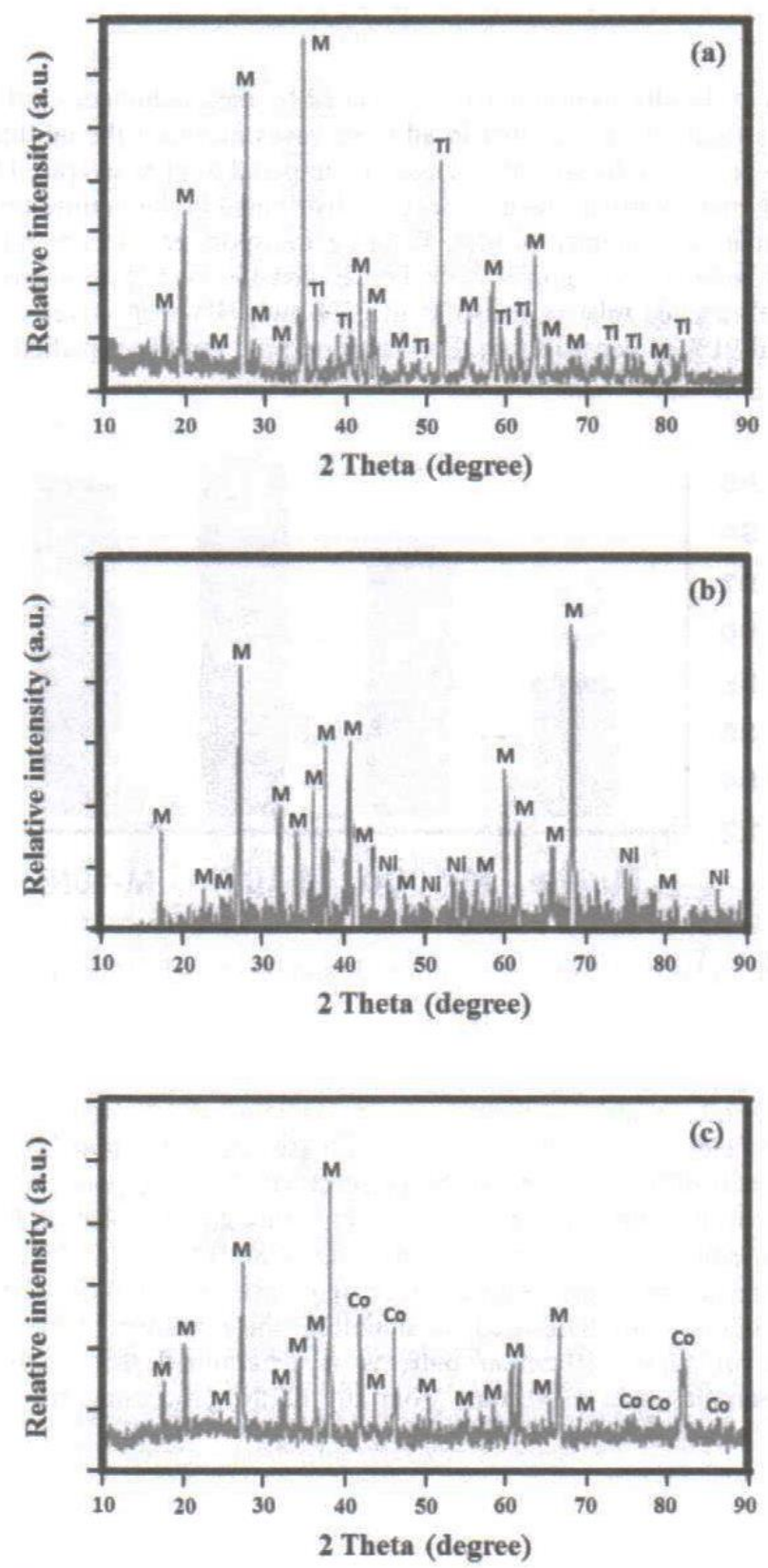

Figure 2. Patterns of X-ray diffraction of the base compounds mullite sintered at $1400^{\circ} \mathrm{C}$ during 1 hour. (a) mullite/Ti, (b) mullite/Ni and (c) mullite/Co $\mathrm{M}=$ Mullite, $\mathrm{Ti}=$ Titanium, $\mathrm{Ni}=$ Nickel, $\mathrm{Co}=$ Cobalt. 


\section{Microstructure}

Figure 3 shows micrographs taken with an optical microscope in the three study materials. In these micrographs, are observed two phases, the opaque corresponds to the ceramic matrix (mullite) whereas the clear and bright phase corresponds to the reinforced metal used in each case. In samples with nickel and cobalt they are observed the formation of porosity, while in the sample reinforced with titanium porosity is not observed. In each case there is a good and homogeneous distribution of the metallic phase; even in the case of the titanium sample, metal distribution is better than in the other two cases.
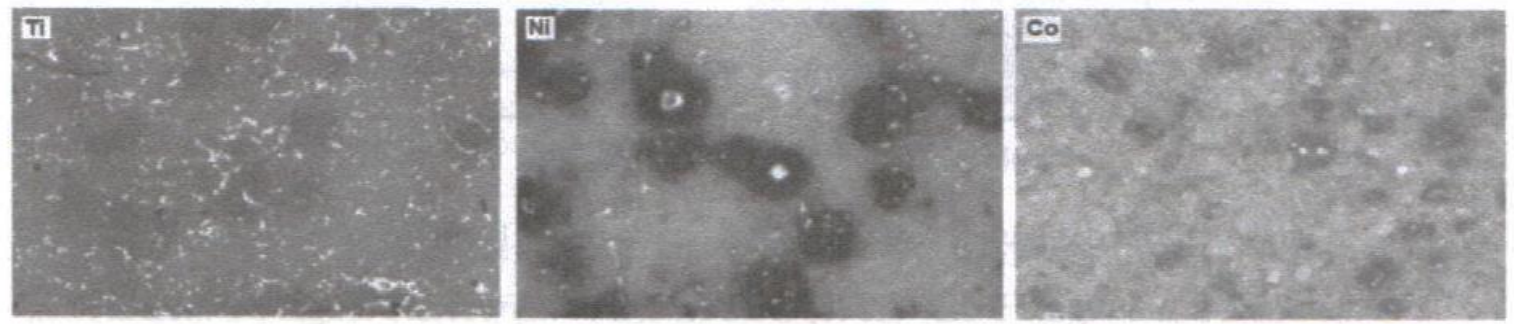

Figure 3. Optical micrographs of the three studied materials. Mullite/Ti, Mullite/Ni, Mullite/Co.

Mechanical properties ( $\mathrm{HV}$ and $\mathrm{K}_{\mathrm{IC}}$ )

Measurements results of micro hardness $(\mathrm{HV})$ and fracture toughness $\left(\mathrm{K}_{\mathrm{IC}}\right)$ evaluated in studied materials are presented in Table 2 . The sample reinforced with titanium presents greater hardness, the values of micro hardness of the other two samples have similar values for magnitude, although the sample with additions of cobalt is a little harder than that with nickel. Pure mullite hardness value is above these last two, and bit below the sample with titanium. A clear effect of the metals used as reinforcement on the hardness of mullite is shown in Figure 4. Where apparently when they were used titanium or cobalt are not significant differences in the hardness of mullite. However, when nickel is added to this the same hardness decreases considerably.

Table 2. Relative density, hardness and fracture toughness of study materials.

\begin{tabular}{|l|c|c|c|}
\hline \multicolumn{1}{|c|}{ Sample } & $\begin{array}{c}\text { Relative density } \\
(\%)\end{array}$ & $\begin{array}{c}\text { Hardness } \\
(\mathbf{G P a})\end{array}$ & $\begin{array}{c}\mathbf{K}_{\mathbf{I C}} \\
\left(\mathbf{M P a m}^{-1 / 2}\right)\end{array}$ \\
\hline Pure mullite & 86 & $9.75+/-0.24$ & $1.51+/-0.23$ \\
\hline Mullite/10\% vol. Ti & 95 & $9.92+/-0.17$ & $3.27+/-0.25$ \\
\hline Mullite/10\% vol. Ni & 94 & $8.95+/-0.22$ & $2.12+/-0.21$ \\
\hline Mullite/10\% vol. Co & 91 & $9.56+/-0.21$ & $2.43+/-0.27$ \\
\hline
\end{tabular}




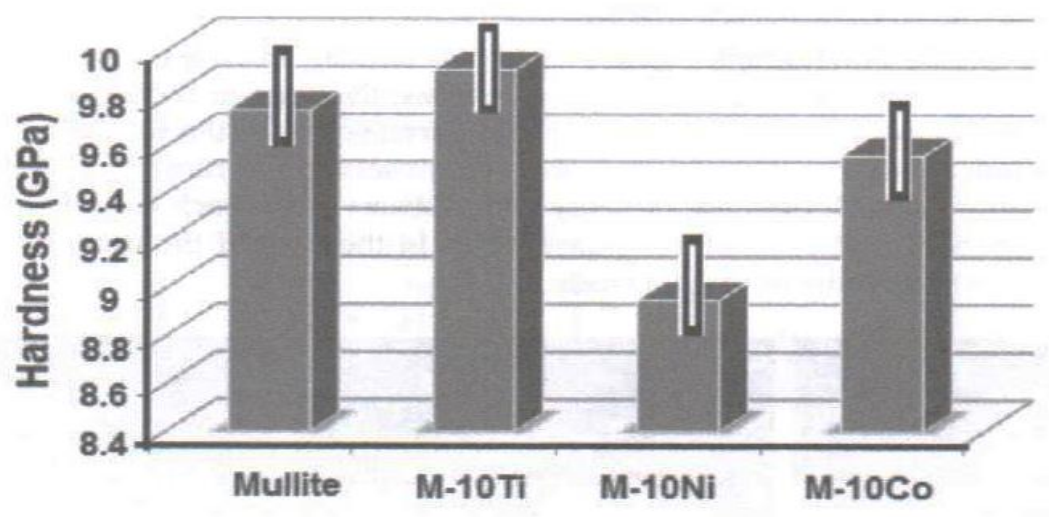

Figure 4. Effect of metals reinforcement on the micro hardness of mullite.

In the Table 2 and Figure 5 they are reported results of the fracture toughness measured in the same samples. Figure 5 shows that the mullite fracture toughness was just $1.51 \mathrm{MPam}^{-1 / 2}$, well below the theoretical value of $2 \mathrm{MPam}^{-1 / 2}$ reported for the same in the literature ${ }^{10}$, the main reason for this difference is the low density of the processed samples of mullite here. However, when mullite is reinforced with a metal such as titanium their fracture toughness increases up to $3.27 \mathrm{MPam}^{-1 / 2}$, which is equivalent to a $100 \%$ improvement in this property. On the other hand, when mullite is reinforced with nickel or cobalt their fracture toughness increases to 2.12 and $2.43 \mathrm{MPam}^{-1 / 2}$ respectively, equivalent to $33 \%$ and $61 \%$, being very significant improvements in this mechanical property improvements. This situation may be due to several factors, the first is the degree of densification reached by samples when a metal is added in them. The second would be the good distribution of the metallic particles in the ceramic matrix. A third is surely good adhesion between the metals used and the ceramic mullite. Altogether, these factors significantly improve the toughness of mullite. Different authors have reported that the mechanism of reinforcement in ceramic/metal composites is because of crack bridging and crack deflection caused by the reinforcing metal particles ${ }^{4,10}$.

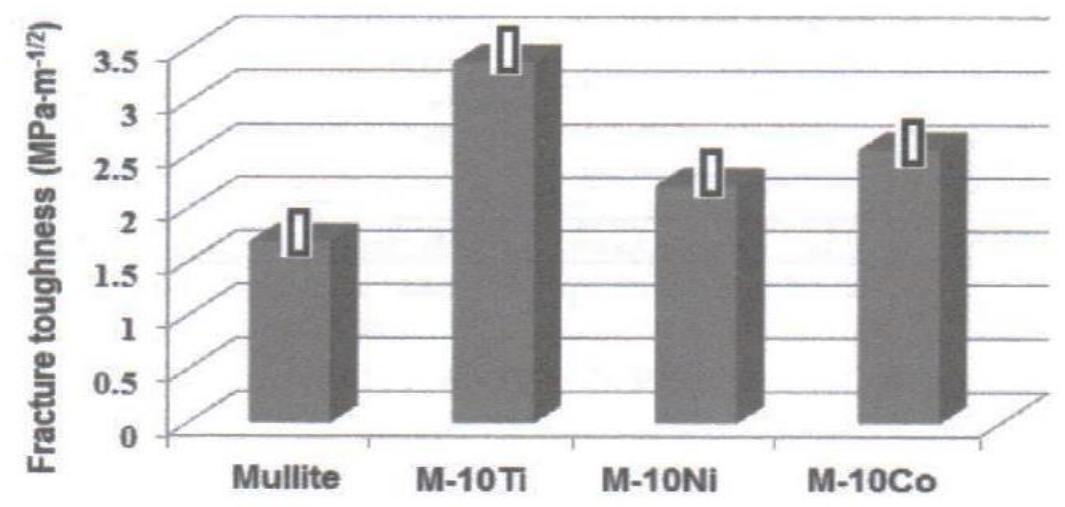

Figure 5. Effect of metals reinforcement on the fracture toughness of mullite. 


\section{CONCLUSIONS}

- Through the proposed methodology, is possible the manufacture of mullite-based composites reinforced with metal particles.

- X-ray diffraction patterns indicate the presence of two crystalline phases in the three studied cases, where mullite is the main component.

- The mullite composite reinforced with titanium particles presents best degree of densification and therefore greater hardness and fracture toughness.

- In the three case studies the fracture toughness of mullite was considerably improved, the mechanism of strengthening is due to crack bridging and crack deflection

Acknowledgments. The materials processing laboratories facilities given by UAM-A, UAEM and UPV is appreciated. Authors wish to thank to the Department of Materials of UAM-A for the financial support given through project 2260235.

References

${ }^{1}$ Y. Miyamoto, W.A. Kaysser, B.H. Rabin, A. Kawasaki, and R.G. Ford, (eds.): Functionally Graded Materials; Design, Processing and Applications, Kluwer Academic, USA, (1999).

${ }^{2}$ J. K. Wessel, The Handbook of Advanced Materials, John Wiley \& Sons, New York, (2004).

${ }^{3}$ Handbook of Chemistry and Physics, $90^{\text {th }}$ edition, CRS Press, R.C. Weast editor. D90 (2009).

4 O.L. Ighodaro and O.I. Okoli, Fracture Toughness Enhancement for Alumina: A Review Systems International Journal of Applied Ceramics Technology, 5, 313-323 (2008).

${ }^{5}$ E. Rocha-Rangel, E. Refugio-García, J.G. Miranda-Hernández and E. Terrés-Rojas, Fracture Toughness for Metal-Reinforced Alumina, Journal of Ceramic Processing Research, 10, 744-747 (2009).

${ }^{6}$ V. Mercedes, Doctoral Thesis, Universidad Autónoma de Madrid, Instituto de Ciencia de Materiales de Madrid, Spain (2003).

7 A. Feder, I. Llanes and M. Anglada: Efecto de la Nitruración en la Degradación Hidrotérmica de Circonia Tetragonal Policristalina estabilizada con $\mathrm{Y}_{2} \mathrm{O}_{3}$, Boletín Sociedad Española de Ceramica, 43, 47-52 (2004).

${ }^{8}$ R. Sivakumar, T. Nishikawa, S. Honda and H. Awaji, Fabrication and Mechanical Properties of Molybdenum Reinforced Mullite Matrix Composites by Pulse Electric Current Sintering Technique, 25th Annual Conference on Composites, Advanced Ceramics, Materials, and Structures: B: Ceramic Engineering and Science Proceedings, 22, 35-42 (2008).

${ }^{9}$ Z. Zuoguang, W. Mingchao, L. Min and Sun Zhijie, Sintering and Mechanical Properties of Mullite-Reinforced Boron Carbide Matrix Composite, Journal of the American Ceramic Society, 92, 1129-1132 (2009).

${ }^{10}$ Mullite Processing, Structure and Properties, Topical Issue, J. Am. Ceram. Soc., 74, (1991).

${ }_{11}$ M. Sacks and H.W. Lee, A Review of Power Preparation Methods and Densification Procedures for Fabricating High Density Mullite, Ceram. Trans. 6 Mullite and Mullite Matrix Composites, Ed. by S. Somiya, R.F. Davis and J.A. Pask, 167-207 (1991).

${ }^{12}$ ASTM, ASTM C 373 - Test method for water absorption, bulk density, apparent porosity, and apparent specific gravity of fired white ware products, USA, (2004).

${ }_{13}$ ASTM C1327-08, Standard Test Method for Vickers Indentation Hardness of Advanced Ceramics, Annual book of ASTM Standards, 15.01, (2008).

${ }^{14}$ ASTM C1421-10, Standard Test Method for Determination of Fracture toughness at room temperature of Advanced Ceramics, Annual book of ASTM Standards, 15.01, (2010). 
Fracture Toughness Enhancement of Mullite-Ceramics Reinforced with Metals

${ }^{15}$ E. Rocha Rangel, Chapter: Fracture Toughness Determinations by Means of Indentation Fracture, Book: Nanocomposites with Unique Properties and Applications in Medicine and Industry, Publisher INTECH, Croacia, (2011).

52. Processing and Properties of Advanced Ceramics and Composites VI 


\section{Author Index}

Abhinav, P., 197

Apostol, N., 123

Bencheikh, M., 225

Bergner, A., 55

Bi, N., 93

Bielawski, M., 83

Bolduc, M., 83

Boualleg, S., 225

Bouzid, M., 235

Bridge, J. W., 65

Burkert, A., 255

Caccia, M., 15

Chaves Panta, P., 137, 147

Chen, L., 267

Chen, Y.-F., 167

Clastres, P., 225

Czympiel, L., 117

Djadi, A., 235

Echavarría Méndez, N. L., 37

Esparza Esparza, B., 105

Esparza-Vázquez, S. J., 37

Fakolujo, O. S., 83

Farooque, M., 267

Fayomi, O. S. I., 245
Fernandez, C. P., 281

Fernández, J. M., 117

Fisher, R., 65

Frank, M., 117

Fukushima, J., 293, 313, 321

Garcia, D., 281

Garcia García, R. R., 37

Gerhardt, R. A., 27

Guechtoulli, S., 235

Gümpel, P., 255

Gunnewiek, R. F. K., 303

Gutiérrez-Pardo, A., 117

Hayashi, Y., 293, 321

Hilmi, A., 267

Hirota, K., 3

Ho, J., 167

Hörtnagl, A., 255

Ikegaya, T., 205

Jian, T., 267

Jitianu, A., 123

Jitianu, M., 123

Juang, F.-S., 167

Karnopp Forte, S., 137, 147

Karpenko, M., 255 
Kashimura, K., 367

Kato, M., 3

Kaur-Bhatia, R., 123

Kawahira, K., 339

Kiminami, R. H. G. A., 281, 303

Kumar, C. S. S., 155

Kumar, K. V., 71

Kungl, H., 215

Lai, T., 65

Lehmann, J., 255

Li, G., 93

Li, S., 93

Link, G., 303

Liu, Y., 93

Li, Y. S., 155

Lin, S., 175

López-Hernández, J., 37

Loto, C. A., 245

Mathur, S., 117

Merati, A., 83

Mikoshiba, S., 347

Miranda Hernández, J. G., 45

Mitani, T., 367

Morales Hernández, A., 105

Muñoz Saldaña, J., 105

Muraca, A., 123

Narciso, J., 15

Nganbe, M., 83

Ning, X.-S., 93

O'Connor, N., 123

Ogawa, T., 205

Pandey, R. K., 175

Panta Romero, R. P., 137

Papac, M., 215

Pérez Bergmann, C., 137, 147

Peterson, M., 65

Popoola, A. P. I., 245

Pramanick, B., 197

Pruyn, T. L., 27

Ramírez-Esparza, A. D., 37
Ramírez-Rico, J., 117

Ravinder, D., 71

Refugio-Garcia, E., 37, 45

Rocha-Rangel, E., 37, 45

Rodríguez-García, J. A., 37, 45

Sant, S. B., 197

Sato, M., 313

Sato, N., 321

Scantlin, A. A., 175

Shibaya, K., 3

Shinohara, N., 367

Skaria, B. M., 197

Sreenivas, K., 197

Sridhar, R., 71

Stapleton, W. A., 175

Sumi, T., 347

Sunako, M., 339

Sun Zampiva, R. Y., 147

Sutanto, I., 175

Taguchi, H., 3

Takayama, S., 313

Takizawa, H., 293, 321

Taniguchi, S., 339, 347

Tayler, G. V. A., 357

Tolman, K., 215

Trapaga Martínez, G., 105

Ubic, R., 215

Wang, B., 93

Williams, P., 357

Wong, B., 329

Wu, R., 167

Yanagawa, A., 367

Yang, L., 155

Yang, Q., 155

Yoshikawa, N., 339, 347

Yoshimura, T., 367

Yuh, C., 267

Zabotto, F. L., 281

Zárate Medina, J., 105

Zhang, C., 155 